\title{
Fallopian Tube Cancer Clinical Distant Metastasis TNM Finding v7
}

National Cancer Institute

\section{Source}

National Cancer Institute. Fallopian Tube Cancer Clinical Distant Metastasis TNM Finding v7. NCI Thesaurus. Code C89689.

A clinical finding about one or more characteristics of fallopian tube cancer, following the rules of the TNM AJCC V7 classification system as they pertain to distant metastases. 